\title{
The influence of lithology and tectonics on the development of the karst landscape in the Dong Van Global Geopark, NE Vietnam
}

\author{
Wpływ litologii i tektoniki na ukształtowanie krajobrazu krasowego \\ Geoparku Dong Van, NE Wietnam
}

\section{Manh Ha Doan', Elżbieta Gałka*}

${ }^{1}$ Hanoi University of Mining and Geology, Faculty of Geosciences and Geoengineering;

No. 8 Vien street, Duc Thang Ward, North Tu Liem, Hanoi, Vietnam

1,2 AGH University of Science and Technology, Faculty of Geology, Geophysics and Environment Protection;

al. Mickiewicza 30, 30-059 Kraków, Poland

'doan@student.agh.edu.pl,'2egalka@agh.edu.pl
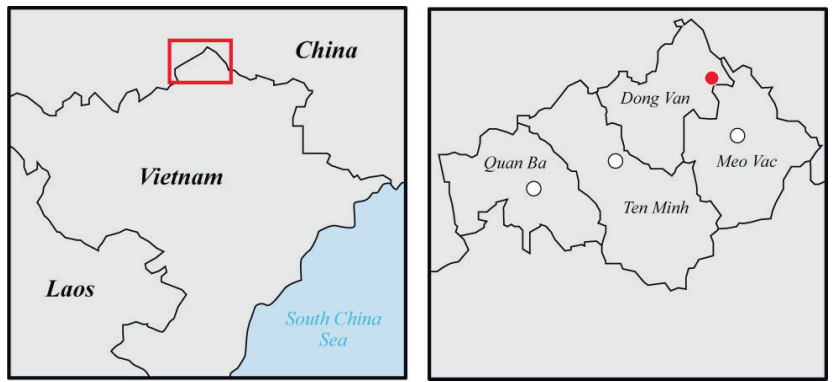

Article history:

Received: 19 March 2018

Accepted: 10 October 2018

Available online: 8 November 2018

(C) 2018 Authors. This is an open access publication, which can be used, distributed and reproduced in any medium according to the Creative Commons CC-BY 4.0 License requiring that the original work has been properly cited.

\begin{abstract}
The Dong Van Karst Plateau Geopark is located in the mountainous area of the northern part of Vietnam. It became the 77th member of the Global Geoparks Network in 2010. The Dong Van Karst Plateau Geopark is a unique combination of breathtaking scenery and culture of ethnic groups, with many potential values such as its geoheritage, biological diversity and historical places, which attract many domestic and foreign visitors. Up to $60 \%$ of the area of this geopark is covered by karst. Its topography is strongly dissected by deep river gorges with steep slopes, and this area has experienced several deformational phases from the Middle Cambrian/Early Ordovician, to the Cenozoic. These elements contributed to the breathtaking scenery of the Dong Van Karst Plateau Geopark, the first global geopark in Vietnam and the second in South-East Asia.
\end{abstract}

Key words: Dong Van Global Geopark, karst geomorphology, ethnic groups, sustainable development

Treść: Geopark Dong Van Karst Plateau położony jest w górzystym rejonie pólnocnej części Wietnamu. W 2010 roku, jako 77 geopark, dołaczyt do Światowej Sieci Geoparków (Global Geoparks Network). Wyjątkowość krajobrazu Geoparku Dong Van Karst Plateau wynika z obecności form rzeźby krasowej, jak również geodziedzictwa, różnorodności biologicznej i historycznej miejsc. Przyciaga on wielu krajowych i zagranicznych turystów. Istotne jest również, że zamieszkuja tu różne grupy etniczne. Obszary krasowe silnie rozcięte głębokimi dolinami rzek o stromych stokach zajmuja $60 \%$ powierzchni geoparku. Teren ten zostat poddany kilku fazom deformacyjnym, trwajacym od środkowego kambru/wczesnego ordowiku do kenozoiku. Powyższe elementy tworza wspólnie obecny charakter krajobrazu Geoparku Dong Van Karst Plateau, pierwszego światowego geoparku w Wietnamie i drugiego w potudniowo-wschodniej Azji.

Slowa kluczowe: Geopark Dong Van, rzeźba krasowa, grupy etniczne, zrównoważony rozwój 


\section{Introduction}

The Socialist Republic of Vietnam is a country located in South-East Asia, bordered by the ocean on the east and south, China on the north and Cambodia and Laos, on the west. With the area of $329,000 \mathrm{~km}^{2}$, it has about 93,7 million inhabitants. Hanoi is the capital city of Vietnam, located in the central part of the Red River Delta, where Ho Chi Minh published the Independence Declaration on September $2^{\text {nd }}, 1945$.

Until now, Vietnam was sometimes still imagined through the lens of war by many foreigners, but in reality, we cannot deny that it is a beautiful country with natural landscapes and peaceful life. It has been over four decades since the official unification of the country and two decades since the end of the US trade embargo imposed on Vietnam. People in this Far-East country have done appreciable work. Obviously, Vietnam is a specific recommendation among travel destinations. With a 3,260 km long coastline and hundreds of river mouths, and wetlands, thousands of diversed islands and coral reefs, as well as a huge area of the marine region and continental shelf, Vietnam has a high potential of geoheritage and very good prospect for creation of a geopark and geotourism development (Pham et al., 2000).

Tourism was not recognized as an important position in the business plan in the past, but it has become the current trend in Vietnam, satisfying both physical and mental needs of humans (The Political Bureau of the Party Central Committee of Vietnam, 2017). According to the statistics of the World Bank and the Vietnam National Administration for Tourism, the number of tourist arriving in Vietnam has increased significantly from $1,315,000$ in 1995 to $10,013,000$ in 2016, whereas the total international arrivals in the first 10 months of 2017 reached 10,473,230; meaning an increase of $28,1 \%$ in comparison with the same period of 2016 (www1). Chinese tourists account for the largest number of arrivals $-30.99 \%$ in total and Koreans take the second place with $18.46 \%$.

Geological research activities applied to geotourism and geoheritage of Vietnam were started in the first decade of the 21 st century by geoscientists. Several papers were published during this period (Deharveng at al., 2004; Krobicki et al., 2006; Pająk et al., 2006). The most popular geotouristic objects are Ha Long Bay, Sapa, Lam Vien Plateau, Lan Ha Bay, Trang An complex landscape and Da Nang city.

With the support from the government and foreign organizations, some initial but noteworthy successes in setting up geoparks, and planning the geoconservation sites have been achieved, especially in the northern part of Vietnam. The Dong Van Karst Plateau Geopark (DVKP) became the 77th member of the Global Geoparks Network on October 10 $0^{\text {th }}, 2010$.
It became the first Global Geopark in Vietnam, and the second one in Southeast Asia (www2).

\section{Methodology}

The field trip was carried out with the support from the Department of Marine Geology, Faculty of Geosciences and Geoengineering, Hanoi University of Mining \& Geology, Vietnam. The trip route was created based on the distribution of geosites and geological boundaries. The infrastructure of geosites was evaluated and documented based on the data provided by the Hanoi University of Mining \& Geology and the Vietnam Institute of Geosciences and Mineral Resources of the Ministry of Natural Resources and Environment. Documentation management and literature study were carried out at the Department of General Geology and Geotourism, Faculty of Geology, Geophysics and Environment Protection, AGH University of Science and Technology in Kraków, Poland.

\section{The Dong Van Karst Plateau Geopark}

\section{The foundation history}

The Dong Van Karst Plateau Geopark (DVKP) is located in Ha Giang, the mountainous and northernmost province of Vietnam, about $431 \mathrm{~km}$ to the north of Hanoi. Sharing borders with China to the north (Fig. 1), Cao Bang province to the east, Lao Cai province to the west and Tuyen Quang to the southeast, the DVKP covers an area of 2,350 $\mathrm{km}^{2}$, with 253,864 residents in four districts: Meo Vac, Dong Van, Yen Minh and Quan Ba, which equals $29.6 \%$ of the area and $35.8 \%$ of the population of the Ha Giang province. Its average elevation is $1,400-1,600$ meters a.s.l., varying from $174 \mathrm{~m}$ a.s.1. to 2,265 $\mathrm{m}$ a.s.1. The climate of the DVKP has two seasons: rainy and dry. Up to $60 \%$ area of the DVKP is covered by karst, thus, it is the largest karst area in comparison with other regions of Vietnam.

Attempts to find a new, interdisciplinary approach to sustainable development and conservation of the area were actually started in 2001, with the first Belgian-Vietnamese speleological expedition, which led to the development of the VLIR (Flemish Interuniversity Council) Own Initiative project entitled: Integrated capacity building through research-based geopark development in Northeast Vietnam (2007-2012). This project was soon accompanied by a state-funded research project entitled: Assessment of geoheritage potential and recommendation for geopark establishment in North Vietnam (2007-2010), implemented by the same group of scientists from the Vietnam Institute of Geosciences and Mineral Resources (VIGMR) (Tran T.V. et al., 2011). 


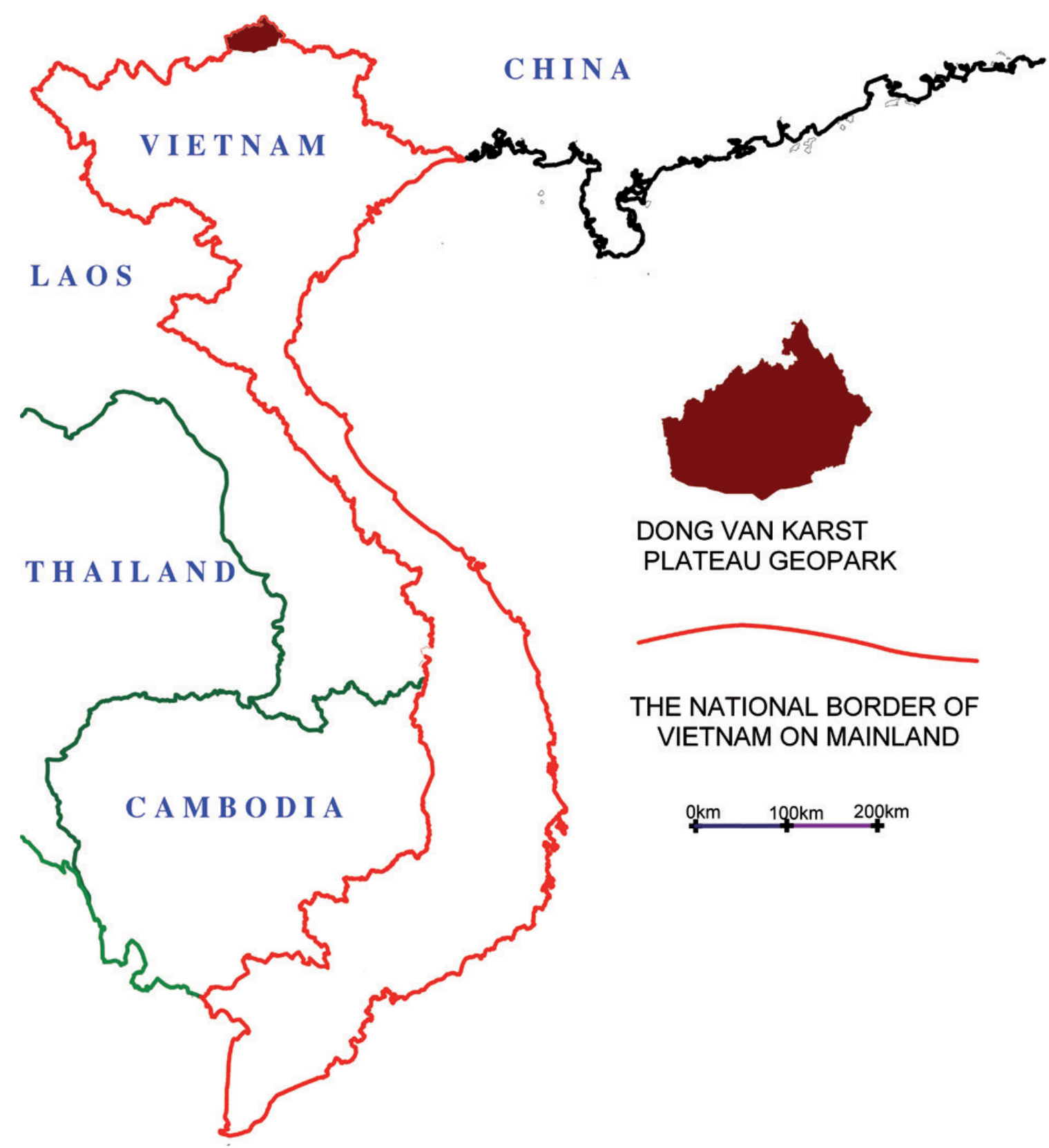

Fig. 1. The location of the Dong Van Karst Plateau Geopark (according to the Ministry of Natural Resources and Environment of Vietnam, 2016)

In September 2009, the International Workshop on the establishment of the DVKP was co-organized by the Ha Giang Province People's Committee, the VIGMR and the Vietnam UNESCO Natcom. Then, the Decisions No.4844/QD-UBND, 4845/QD-UBND and 4846/QD-UBND were published by the local authority on November 19th, 2009, in order to set up the DVKP, its Steering Committee and its Management Board, and to verify the development plan for the DVKP for the next few years. As a result, the DVKP has become the first geopark in Vietnam. In summary, the DVKP became the 77th member of the Global Geoparks Network on October $3^{\text {rd }}, 2010$ (www2).
The DVKP (Fig. 2) is a unique combination of breathtaking scenery and culture of ethnic groups, with many potential values such as geoheritage, including fossils, biological diversity and historical sites, which attract many domestic and foreign visitors. Especially, the community of 17 ethnic groups inhabiting the DVKP area contributes to engaging tourists in visiting features of this area in the form of traditional ethnic group performances and handmade crafts. It is believed that the geopark model will be the optimal solution to balance economic development and conservation in this area. 


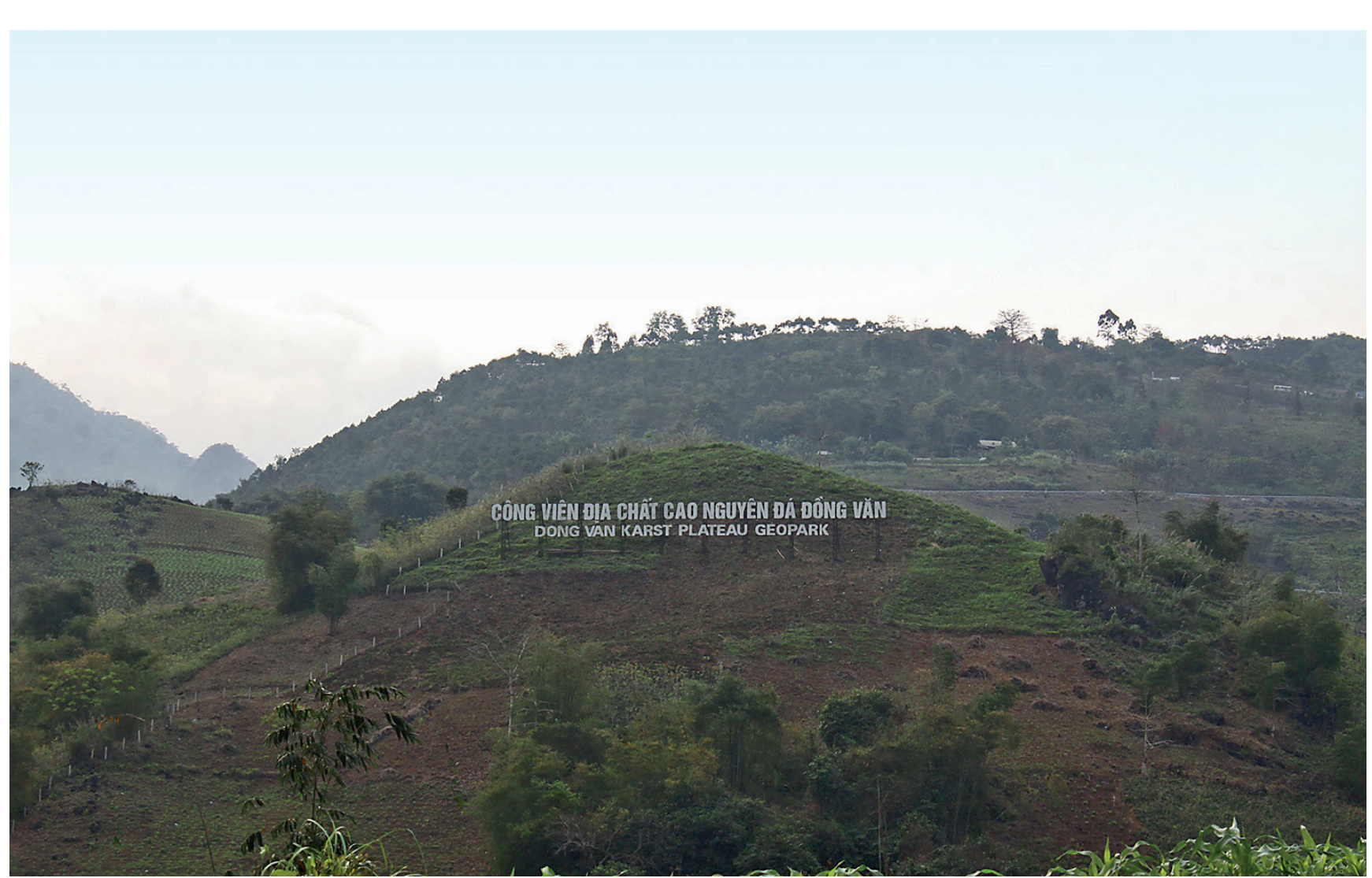

Fig. 2. The welcome panel of Dong Van Karst Plateau Geopark, photo Dao Quoc Bao

\section{Karst geomorphology of the Dong Van Karst Plateau Geopark Geology and tectonic evolution}

The first geological investigation of the Dong Van Karst Plateau was carried out by a French geologist G. Zenin and his team in 1907 (Nguyen, 2011). Until now, several geological investigations have been completed by both Vietnamese and foreign scientists, providing in-depth knowledge about the geological characterization of the DVKP (Fig. 3). This area is divided into seven stages of geologic evolution: 1) Middle Cambrian-Early Ordovician, 2) Middle Ordovician-Silurian, 3) Devonian-Early Carboniferous, 4) Early Carboniferous-Middle Permian, 5) Late Permian-Late Triassic, 6) Jurassic-Cretaceous, and 7) Cenozoic (Tran T.V. et al., 2011). From the paleogological point of view, 19 fossil groups have been found in the DVKP: 1) brachiopods; 2) tabulate corals; 3) rugose corals (Tetracoralla); 4) stromatoporoids; 5) trilobites (Fig. 4); 6) paleofish; 7) foraminifers; 8) tentaculites; 9) conodonts; 10) pelecypods; 11) gastropods; 12) cephalopods; 13) bryozoans; 14) crinoids; 15) ostracods; 16) crustaceans; 17) paleoflora; 18) algae; and 19) chitinozoans (Tran T.V. et al., 2011).

The oldest known rocks in the DVKP include marly shales, clayey shales, oolithic limestones, cherty limestones and limestones deposited under the continental margin condition and quiet tectonic regime during the Middle Cambrian-Early
Ordovician (Nguyen, 2011). The Middle Ordovician-Silurian sedimentary rocks are absent from this region, but the surveying data of neighbouring areas show that from this stage (app. 470-415 Ma ago) sedimentary basins developed between the orogenic belts, as a result of the strong regional differentiation all over the South China plate (Tran T.V. et al., 2011). During the Devonian-Early Carboniferous stage (app. 415-360 Ma ago), there was a strong lateral differentiation of sedimentary environments that formed several types of sedimentary rocks. These deposits unconformably cover the older rocks and contain an abundance of fossils: paleofish, paleoflora, brachiopods, gastropods and ostracods of the Early Devonian (Lochkovian) age (La et al., 2011). The Lower Devonian rocks comprise mottled calcareous siltstones, shales and micaceous sandstones deposited in the coastal sedimentary environment, with continental contribution exposed in a narrow band along the outcrops of the older rocks. The red and yellow shales and clayey limestones are distributed along the northern and southeastern margins of the DVKP, whereas the black limestones with siliceous and calcareous shales occur along the northern margin of the Geopark (Tran T.V. et al., 2011). During the Late Devonian-Early Carboniferous period, the thin bedded limestones, clayey limestones and siliceous shales were formed in the form of belts surrounding the Carboniferous-Permian limestone massifs. 


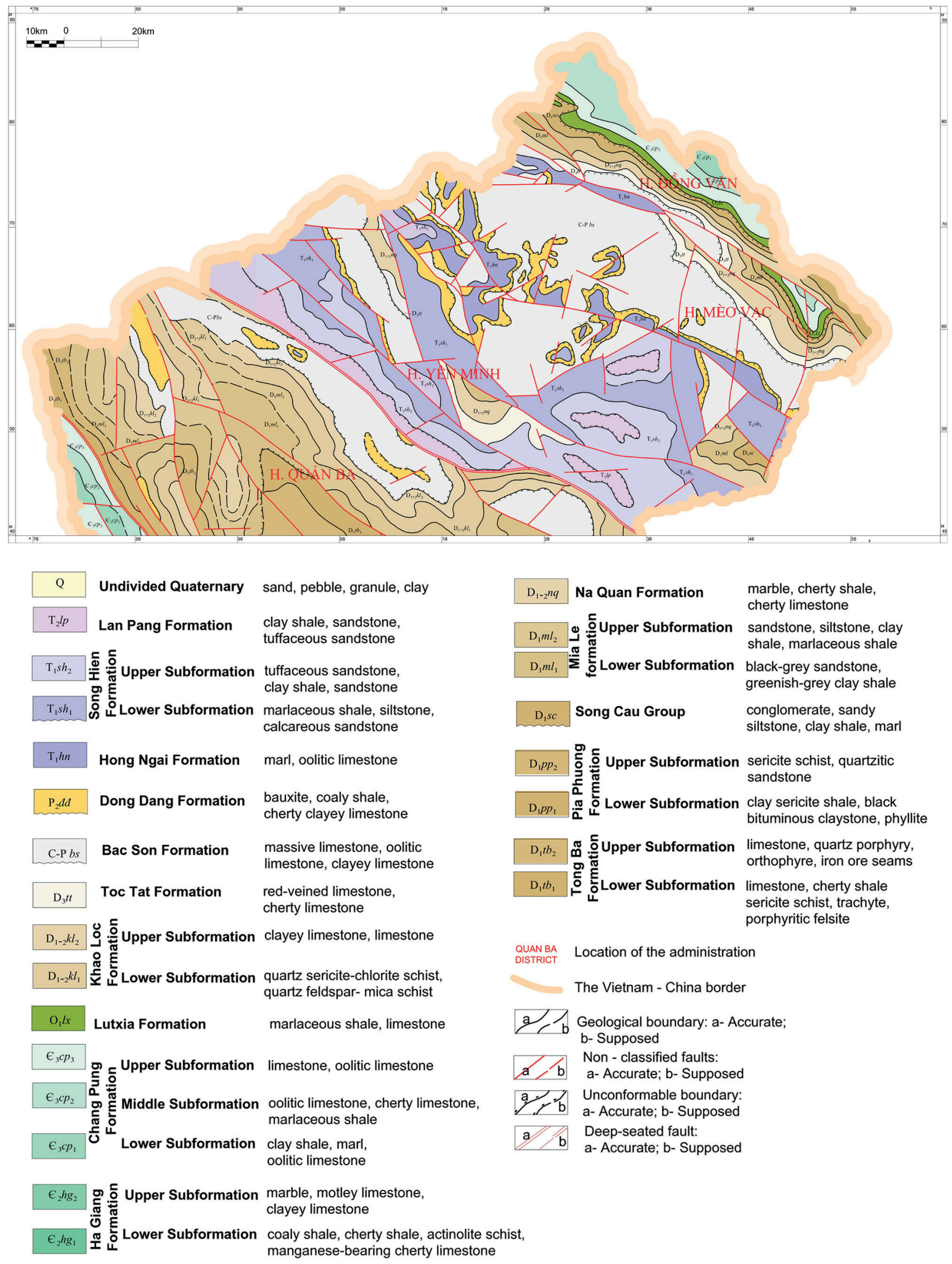

Fig. 3. The geological map of DVKP (after Hoang, 2010) 


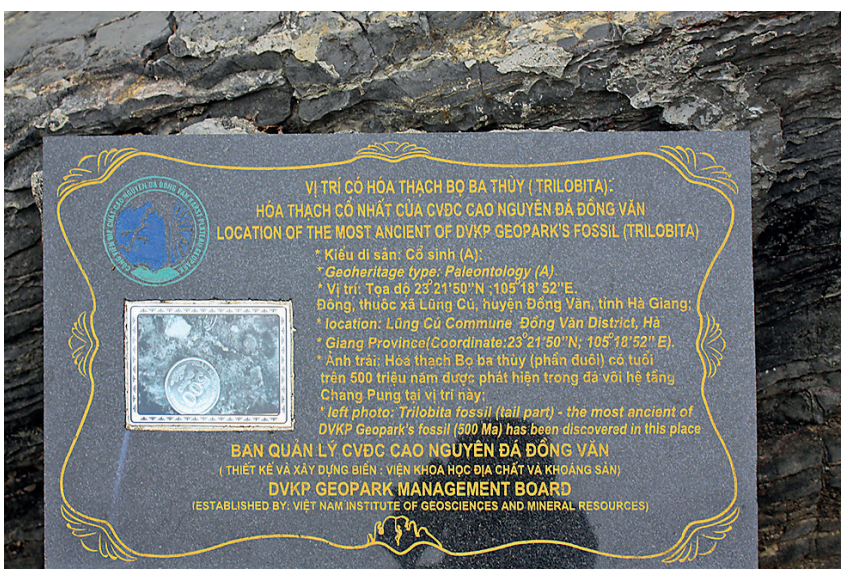

Fig. 4. Commemorative plate placed where trilobite fossils (500 Ma) - the most ancient of DVKP Geopark were found (Lung $\mathrm{Cu}$ village, Dong Van District), photo Dao Quoc Bao

The shallow marine deposits, 1,000-1,200 m thick, representing the Early Carboniferous-Middle Permian stage (app. 360-260 Ma ago) are divided into two successions: lower (dolomitic limestones and dolomites) and upper (grey, lightgrey, fine- to coarse-grained, fossiliferous limestones). Several fossils: foraminifers, corals and brachiopods were indentified within this sequence. This type of sedimentation has continued during the Late Permian-Early Triassic stage (app. 260-245 Ma ago). In the Late Permian, bedded limestones, clayey limestones, siliceous limestones, and calcareous cherts were formed. These sediments were overlain by the Lower Triassic thin-bedded clayey limestones, calcareous shales, dolomitic limestones and oolithic limestones in the northern part of DVKP, and by variegated shales, siltstones, sandstones, calcareous shales with effusive and tuffaceous intercalations in the remaining part. The youngest Upper Triassic sediments were formed in the shallow continental shelf environment and include basal conglomerates, sandstones-gritstones, siltstones, and shales. The Jurassic-Cretaceous rocks were not evidenced due to the lack of outcrops, although magmatic activity (app. 200-65 Ma ago) took place in the whole Northeast Vietnam during this period (Tran T.V. et al., 2011; Tran, 2009).

In terms of tectonic evolution, this area belongs to the northeastern part of Vietnam, where rocks were deformed during several tectonic phases lasting from the Middle Cambrian-Early Ordovician to the Cenozoic (Tran T.H. et al., 2011). The Cenozoic was the most important era that contributed to the unique geomorphology of the DVKP landscape and created favorable conditions for development of karst landscape by the uplift of limestone terrains and the rejuvenation of ancient faults and fracture zones (Pham, 1985).

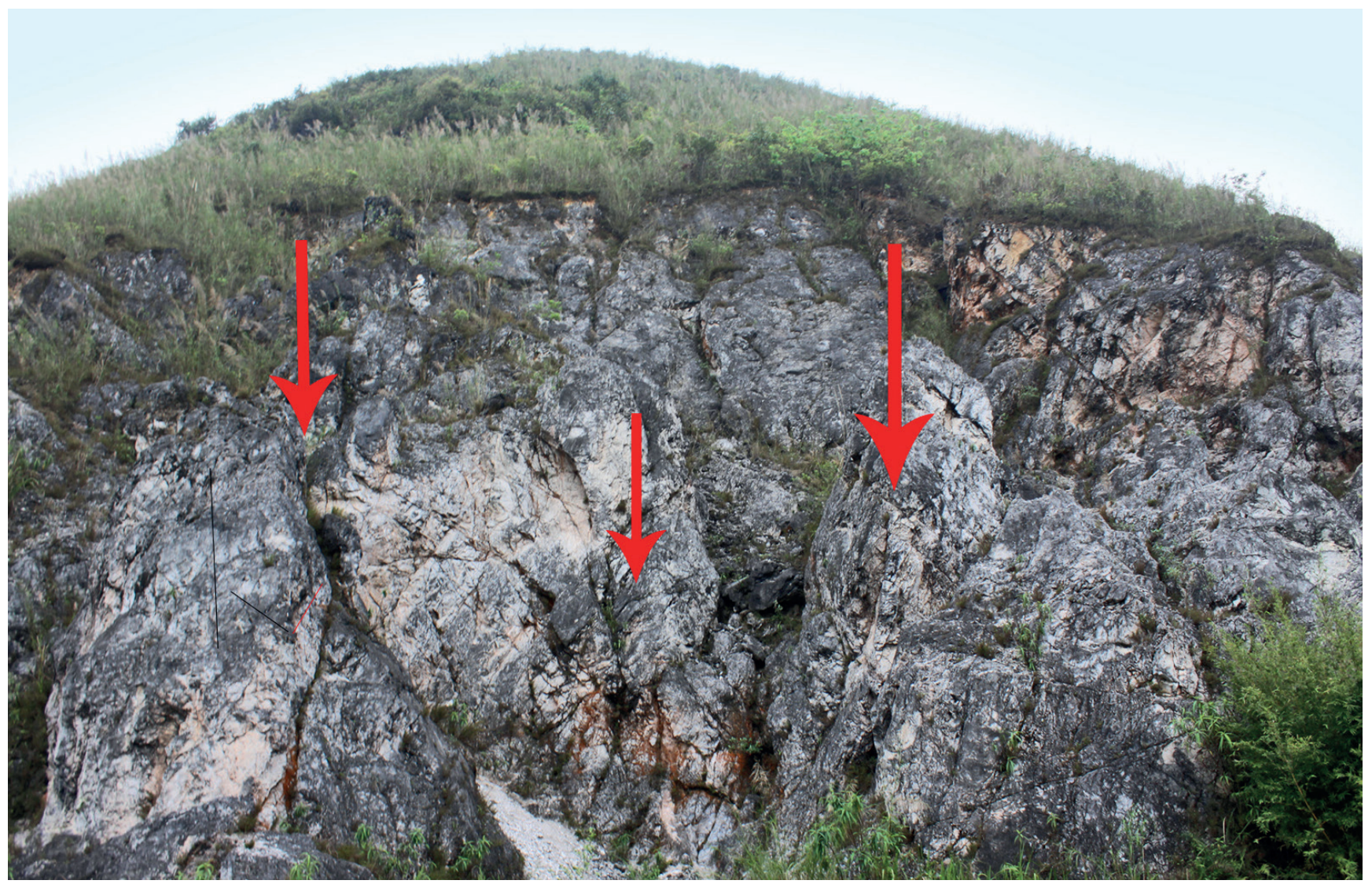

Fig. 5. The fault mirror (slickenside) and deeply crushed limestone zone at Quan Ba district, photo Dao Quoc Bao 
The regional structural pattern was affected by the NW-SE-striking fault system, and was a result of the collision between the Indian and the Eurasian crustal plates, which led to the uplift and the erosion (Tran T.H. et al., 2011). Full-scale geological research of this area was carried out by the cooperation between Belgium and Vietnamese geologists, bringing an overview of DVKP tectonic evolution. Hence, the study area was separated into 3 main parts: Song Gam (Gam River); Song Hien and Lung $\mathrm{Cu}$, separated by two major faults; the Song Gam Fault (in the SW) and the Ma Lau-Dong VanLung Thang Fault (in the NE). The noteworthy faults in the Geopark area are: the Nho Que Fault and the Quan Ba-Huong Cha Fault. The Nho Que deep, dextral, strike-slip, NW-SE-directed fault extends along the Nho Que River, from Chu Sa to Sika, over about $40 \mathrm{~km}$. It provided favorable conditions for circulation of groundwater, which generated local erosion in the Meo Vac district (Vu \& Batelaan, 2011).

The NW-SE-striking Quan Ba-Huong Cha Fault, cutting through Devonian limestones, produced a deeply crushed zone that could be observed in the Quan Ba district, which facilitated the weathering processes in limestones. This was the latest phase of neo-tectonic activity in the DVKP.

The steep fault surface at Quan Ba (Fig. 5) and the Tam Son fault surface (Fig. 6) indicate the strike-slip movement during the formation of the fault and represent evidence of the Quan Ba - Huong Cha fault. The surfaces of both the Quan $\mathrm{Ba}$ and the Tam Son faults are covered with red iron oxides resulting from the circulation of meteoric waters in the fault zone.

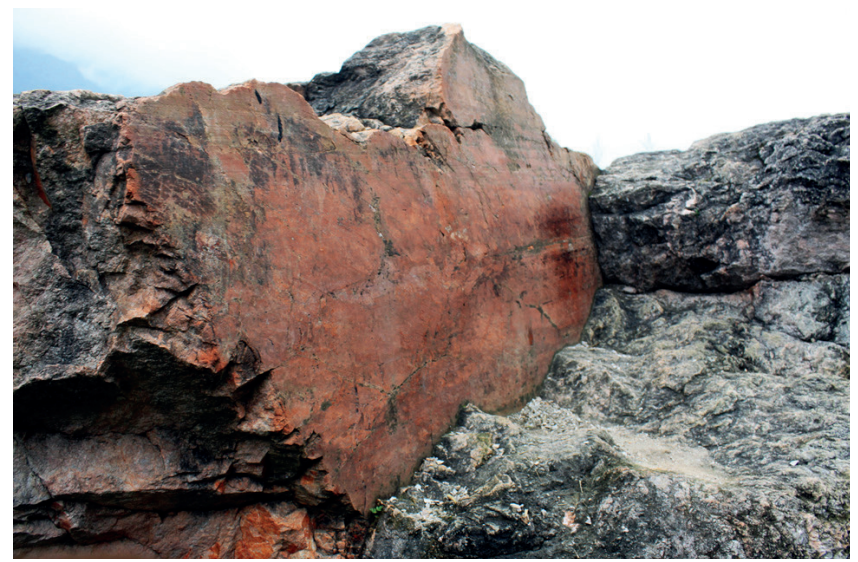

Fig. 6. The fault surface at Tam Son town, photo Dao Quoc Bao

\section{Karst landforms and processes}

Carbonate rocks cover up to $60 \%$ of the area of the DVKP (Fig. 7), mainly in both the Dong Van and the Meo Vac districts. From a topographical point of view, the DVKP relief is strongly dissected by deep river gorges of steep slopes. Thus, it is subjected to severe erosional and denudation processes and rarely covered with topsoil layer (Tran T.V. et al., 2004). According to data after the Vietnam Institute of Geosciences and Mineral Resources, nearly 100 karst caves have been discovered in the DVKP up until now. Both the karst caves and the sinkholes in the DVKP were classified into four groups, considering the elevations of their entrances: $300-600,600-900$, 900-1,200 and 1,200-1,500 m a.s.1 respectively.

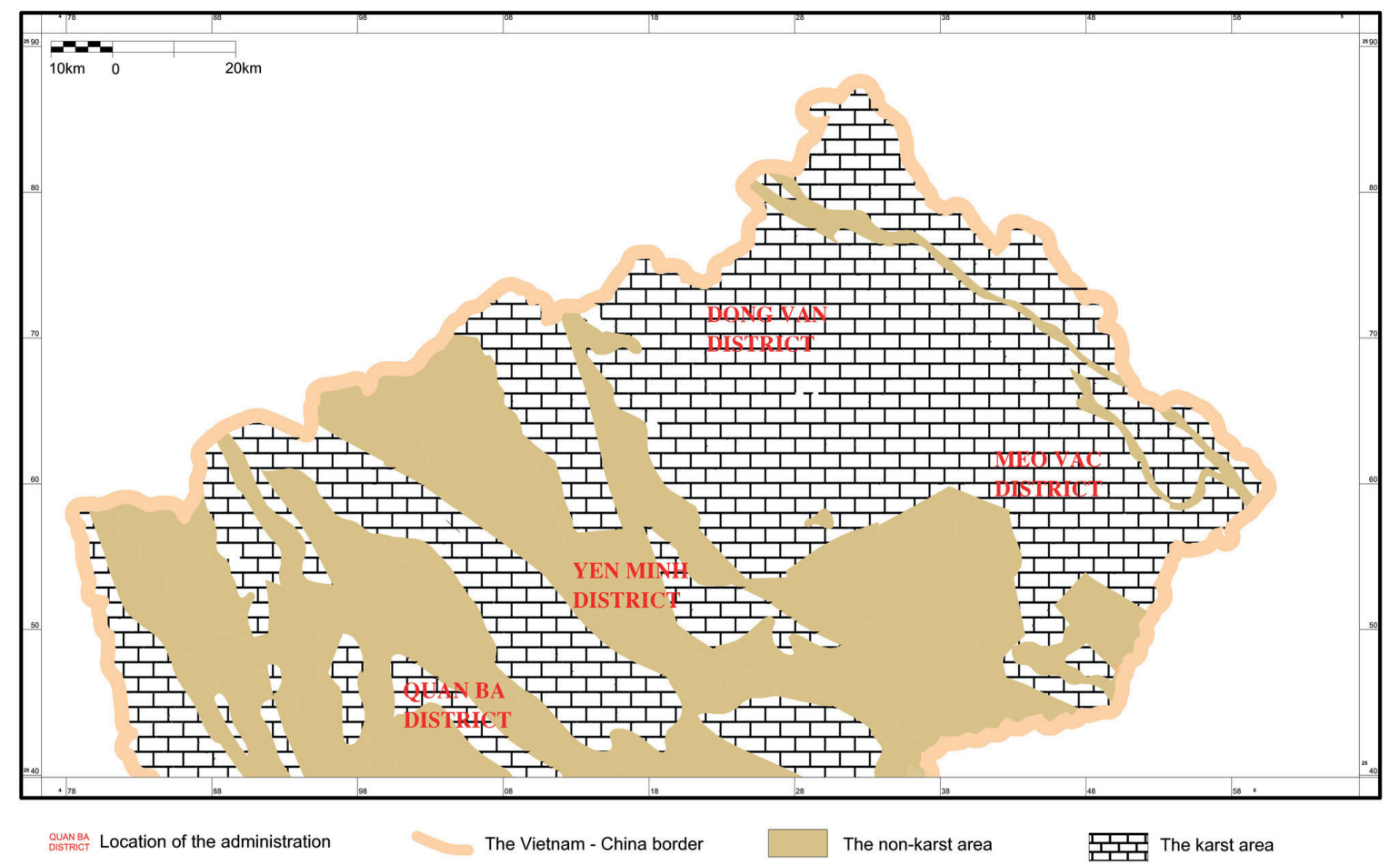

Fig. 7. Distribution of the karst area in DVKP (after Hoang, 2010) 
The elevation group that has the highest density of caves is $300-600 \mathrm{~m}$, and the average density of sinkholes per $1 \mathrm{~km}^{2}$ is 1.4. The DVKP relief comprises slopes with inclinations: $5^{\circ}-15^{\circ}, 15^{\circ}-30^{\circ}$ and $30^{\circ}-45^{\circ}$, accounting for $53.9 \%, 21.9 \%$ and $16.5 \%$ of the study area, respectively (Pham et al., 2013). The DVKP area belongs to the karstified regions of the northeastern Vietnam. In summary, this area experienced the same tectonic events as all karst areas in the northeastern part of the country.

The results of recent geological research show that all the rocks in the northeastern part of Vietnam experienced multiple phases of tectonic events under ductile, brittle-ductile and brittle strain conditions (Tran T.H. et al., 2004; Nguyen, 2005; Nguyen, 2006; Tran \& Vu, 2009). Between the Middle Paleozoic and the Cenozoic, three major tectonic events had happened in this area (Tran T.H. et al., 2011).

The strongest regional tectonic event widely recognized in Vietnam and in southern China took place during the Ordovician/Silurian period (Faure et al., 2009; Tran, 2009). It led to both the uplift and the erosion of carbonate successions, not only in the DVKP, but in the whole of northeastern Vietnam, and produced the thrust zone and fold systems, that deformed the carbonate rocks (Tran T.H. et al., 2011). During the Mesozoic, northeastern Vietnam had been affected by crustal plate collisions and terranes accretion, which formed the proto-southeastern Asia (Hutchison, 1989; Metcalfe, 2005). As a result, carbonate rocks in this area were deformed by widespread, ductile to brittle-ductile, thrust/reverse shearing and associated folding (Tran T.H. et al., 2011). During the last major tectonic event in the Cenozoic, carbonate rocks had been crushed, by brittle, reverse, normal and strike-slip faulting, and extensive fracturing, by the post-orogenic and intra-continental tectonic activities (Tapponnier et al., 1990; Searle, 2006; Tran \& Vu, 2009). In addition, the DVKP is located in a transition zone from the Yunnan Plateau in Southern China, of the elevation 3,000 m a.s.l. to the strongly differentiated mountainous area of northeastern Vietnam located at lower elevations (Tran T.V. et al., 2011). In the W-E direction, it is the transition zone from the Song Chay dome-like uplifted block (3,000 m a.s.1.) to Bac Son-Ha Lang zone located at 1,000 m a.s.1. (Tran T.V. et al., 2011). The thrust/reverse shear, fold and fault zones in the DVKP, which resulted from numerous deformations, play an important role in the circulation of both the groundwaters and surface waters, which influence the karst morphology (Tran T.H. et al., 2011).

Due to the joint action of lithostratigraphic and tectonic factors, the voids within the carbonate bodies became enlarged facilitating the circulation of groundwaters, which gave rise to the erosion and dissolution of crushed carbonate rocks. Hence, caves and sinkholes were formed. The groundwater in this region is at different depths, varying from 18-25 to $80 \mathrm{~m}$ deep at Quan Ba, especially at Meo Vac district, where groundwater is observed at 700-800 m deep (equivalent to local base level of the Nho Que River). Results of geophysical measurements and exploration drilling conducted in this zone indicate that karstification develops from the surface (Nguyen et al., 2013). In Yen Minh and Quan Ba district, the groundwaters supply the Mien River. In Dong Van and Meo Vac district, the ground waters mainly supply the Nho Que River.

Exogenous processes, supported by tropical mountain conditions, strongly adjust the uplifted areas, leading to the slope surfaces and cliffs of different types (tectonic, erosion, erosion-denudation, gravity, e.g. many varieties of cuesta landforms) and accumulative reliefs (river bed, floodplain, and lake deposits). Otherwise, karst landforms are extremely variable and well-symbolized in all kinds of carbonate rocks (peak-cluster cones, karst depressions, caves, blind valleys, sinkholes and underground rivers, travertine terraces, karst pediments, epikarst, residual and rejuvenated karst) (Tran T.V., 2011). Previous studies also show that there are two types of topographic developments in the DVKP. The first topographic type, distributed in a NW-SE direction, was formed by tectonic movement and influenced by major faults. The second, distributed mainly in a NE-SW direction, was formed by exogenous geomorphological processes and also affected by major faults. Geological analysis indicates that ten stratigraphic formations crop out in the study area, but only six of these have correlations with karst landscapes (Pham et al., 2013).

Having a variety of geological structures, embracing a variety of carbonate rock types, and experiencing multiple phases of tectonic evolution and slope erosion (Fig. 8), the DVKP has a spectacular karst landscape. The geosites in the DVKP were classified into four main types: 1) geomorphological; 2) structural-tectonic; 3) stratigraphic-paleontological-lithological paleoenvironmental; and 4) karstic (La et al., 2011). Typical geosites that were classified into geomorphological types are: The Thach Son Than erosional monadnock (Fig. 9), the "rock deserts" (Vietnamese nomenclature) (Fig. 10), the karst cones known in Vietnam as the "Fairy Bosom" Mountains at Heaven's Gate (Fig. 11) and the karst canyon of sub-meridian direction (Fig. 12). The Thach Son Than erosional monadnock is an isolated surviving erosion rock that stands above the surrounding area. "Rock desert" is a sort of landform that is rarely seen elsewhere; hence it could be quite scenic to tourists. The karst cones known as the "Fairy Bosom" Mountains at Heaven's Gate resulted from tectonic activities and washing away processes. The limestone was extremely crushed into powder by the fault and then was washed away, resulting in very soft and gentle relief. The karst canyon of sub-meridian direction is the outcome of strongly dissected relief. 


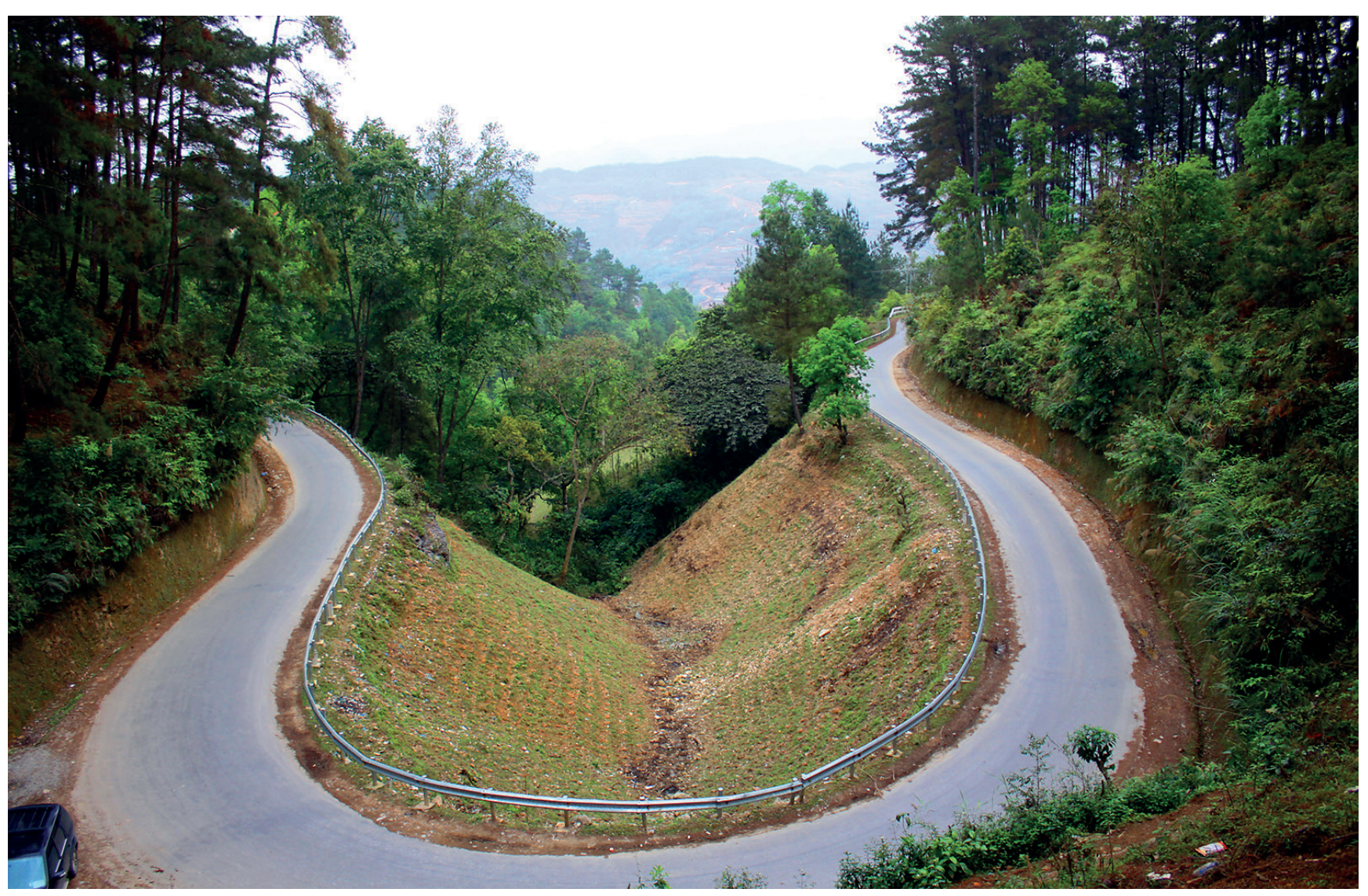

Fig. 8. Karst erosional valley developed within a slope on the Na Khe pass, photo Dao Quoc Bao

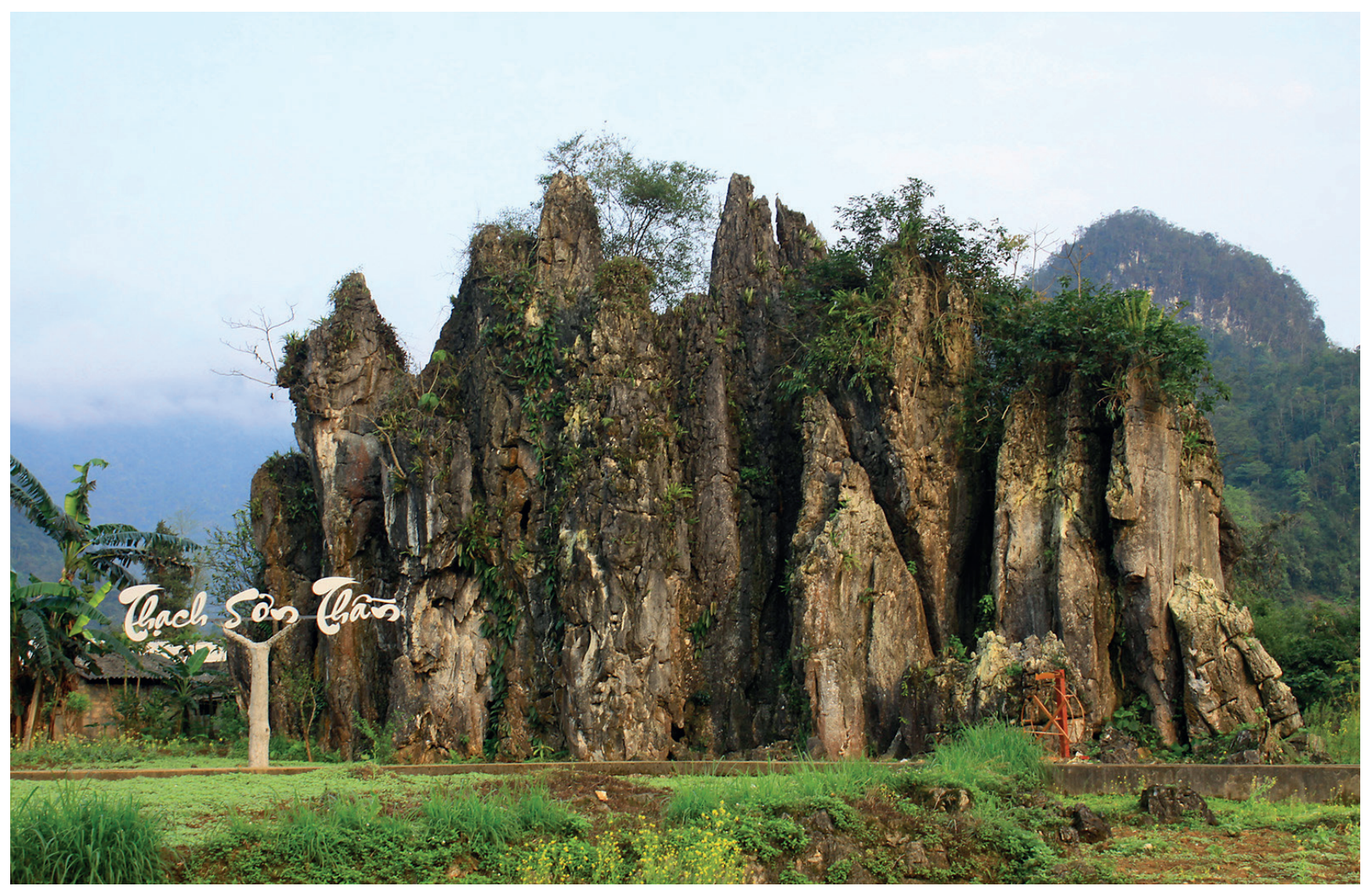

Fig. 9. The Thach Son Than erosional monadnock, photo Dao Quoc Bao 


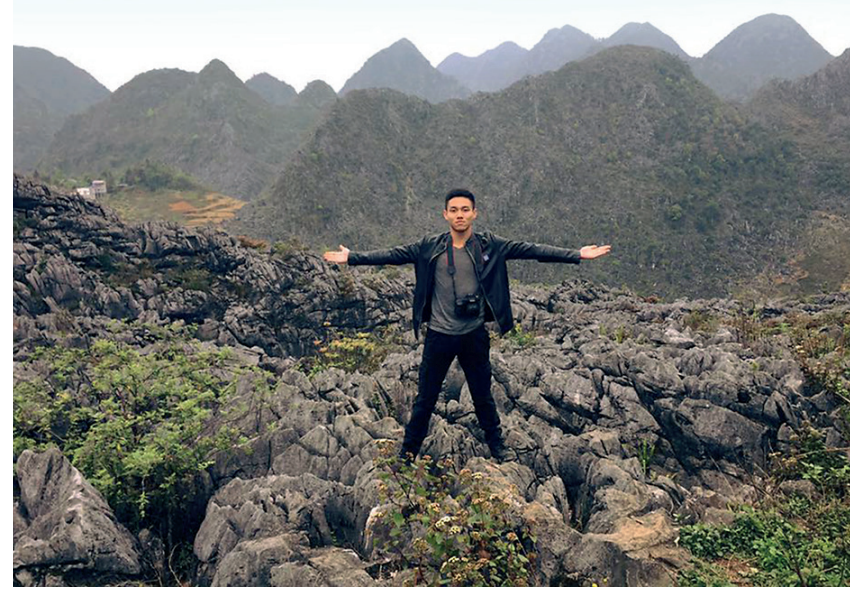

Fig. 10. Limestone ribs and the bare limestone rocks called "rock deserts" in Dong Van district, photo Dao Quoc Bao

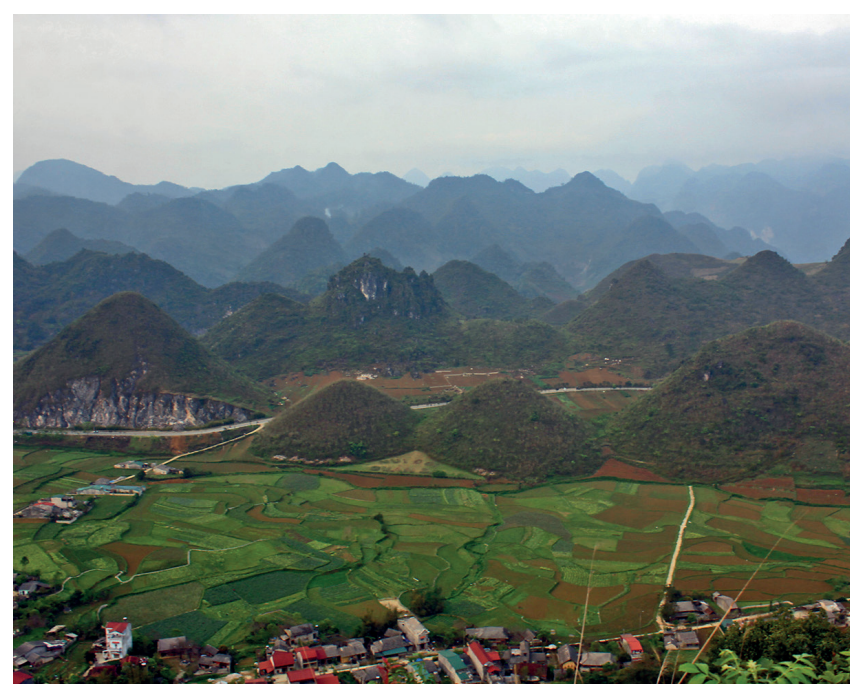

Fig. 11. Karst cones known as the "Fairy Bosom" Mountains at Heaven's Gate, photo Dao Quoc Bao

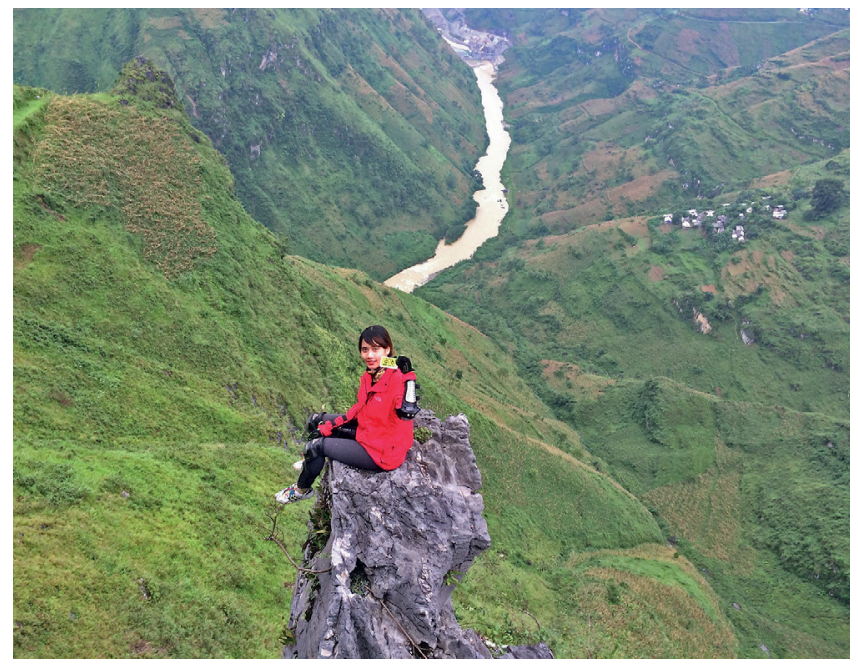

Fig. 13. View from Ma Pi Leng Pass to Nho Que river, photo Mai Phuong Nguyen
All these geomorphological-type geosites resulted from the combined action of weathering processes, different susceptibility of rocks to erosion, deeply dissected relief and dissolution or washing down limestones by seasonal flows (Tran T.V. et al., 2011). Meanwhile, the surface of Quan Ba-Huong Cha Fault (Fig. 5) is a structural-tectonic geosite and the geosite where trilobite fossil (500 Ma) was found. This most ancient trilobite fossil in the DVKP Geopark represents the stratigraphic-paleontological-lithological-paleoenvironmental type.

The karst landscape in the DVKP is important not only for studies on karst processes, but also for tourist inspiration. The road crosses a hogback, the view from the Ma Pi Leng Pass (Fig. 13), and the slopes in Quan Ba district (Fig. 14) are good stopover stations to enjoy the gorgeous scenery of the DVKP.

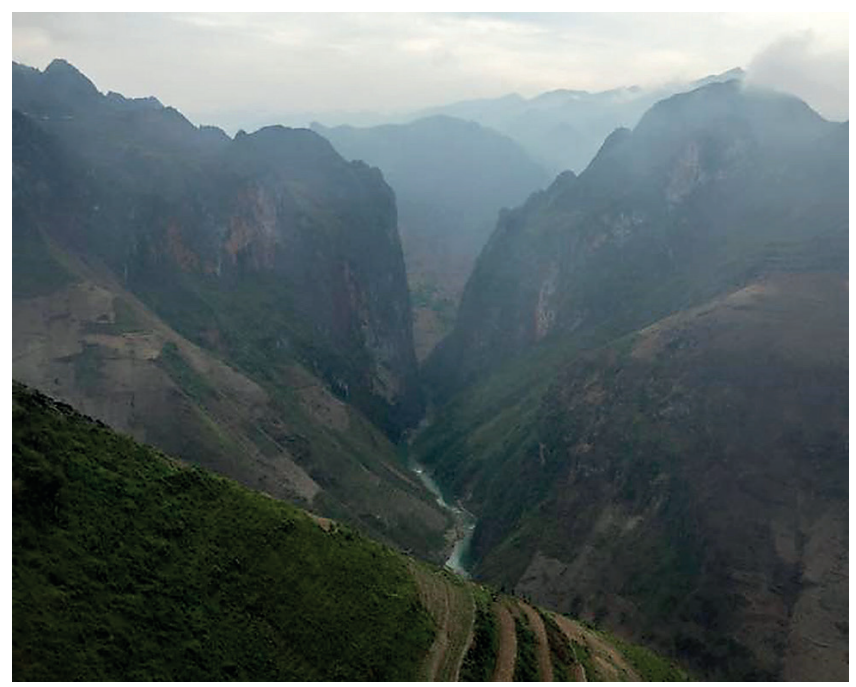

Fig. 12. The Tu San Canyon of sub-meridian direction, photo Dao Quoc Bao

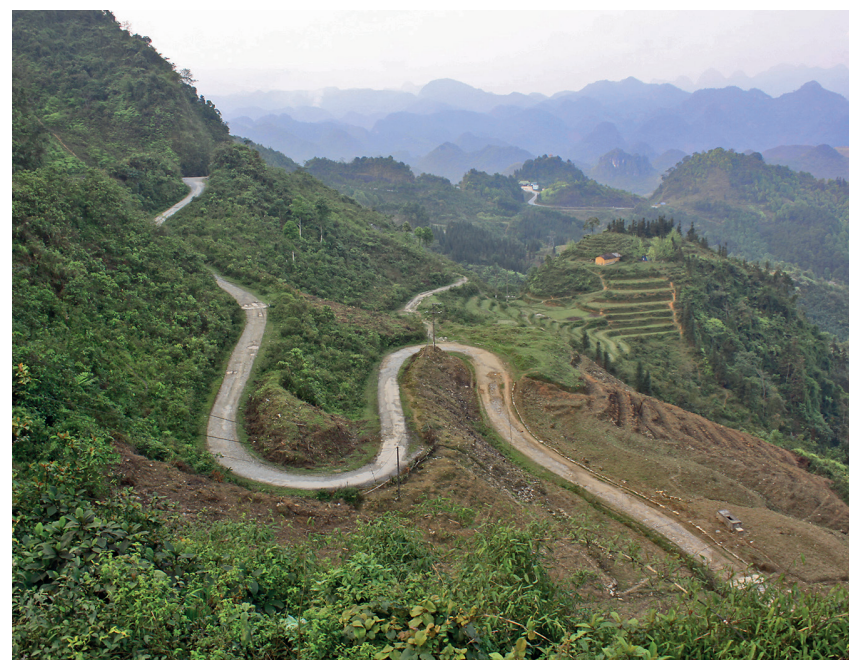

Fig. 14. The slopes in Quan Ba district, photo Dao Quoc Bao 


\section{Geoconservation in the geopark}

Sustainable development is a central goal in geotourism, and to be sustainable, it needs to be carefully planned and managed. In accordance with the current trends, tourists intend to visit natural sites (Newsome \& Dowling, 2010). This is an opportunity and an advantage of the DVKP to become an international tourist attraction. This can only be facilitated by sustainable geotourism development and geoconservation planning. The regional planning and development approach, which is an effective way of management for the DVKP is the Prime Minister's Decision No. 2057/QD-TTg: Approval of the comprehensive planning on tourism development of Dong Van Karst Plateau Geopark, Ha Giang province till 2025 with a vision to (www3). This plan aims to preserve and exploit the natural (including geological) and cultural resources in the DVKP for sustainable geotourism development.

The Management Board, which controls this plan is located in the city center of Ha Giang, and four other regional information centers were built in four districts: Dong Van, Quan Ba, Yen Minh and Meo Vac, in order to provide information and services and recommend the attractions to the tourists and students, both the domestic and foreign investors. The Management Board is a non-commercial unit under the control of the People's Committee of the Ha Giang Province, composed of one head, two deputy heads and three departments: the Department of General Admission, the Department of Heritage and Service Management and the Department of Information \& Foreign Affairs, which are responsible for advising the People's Committee on the implementation of management, preservation, exploitation and promotion of the values of the Geopark, supporting the socio-economic development and contributing to poverty reduction in this area. The regional center in Dong Van district also includes a museum, which has a collection of regional rocks, fossils, publications about the geopark and historical antiques of local people living in the Dong Van Karst Plateau. Tourists can also get free copies of geological maps and leaflets and free Internet connection. The other regional centers in three remaining districts educate about famous sites and details of geological settings of each district.

The geoconservation strategies of the DVKP comprise the following elements: natural habitat protection, geosite protection and cultural conservation. In terms of natural habitat protection, two nature reserve forests named Du Gia (Yen Minh district) and Bat Dai Son (Quan Ba district) have been set up within the DVKP by the authorities of the Ha Giang province. Rare species of regional plants and animals occur there, for instance: Taxus chinesnis (Chinese yew) Rehder, Pinus kwangtungensis (Chinese White Pine) Chun ex and Tsuga chinensis (Chinese Hemlock) Pritzel ex Diels (Hoang et al., 2016). Geosites are distributed within the whole DVKP. Until
2010, 139 geosites had been discovered (La et al., 2011). The authorities of each district are responsible for controlling and protecting the geosites. The People's Committee of Ha Giang Province has declared an incentive policy to encourage both the foreign and domestic investors and provide the tax benefits to companies or groups which invest in geoconservation. All the DVKP is under a high level of protection. Every construction in this area needs an environmental impact assessment report to obtain a building license.

\section{The educational, cultural and promotional activities in the Dong Van Karst Plateau Geopark}

The Dong Van Karst Plateau is also famous for particular types of buckwheat. Numerous buckwheat fields are grown by local people with the financial support from the state budget and technical support from several associations. November is the best time for buckwheat flowering (Fig. 15), creating a wonderful scene - the roads and the mountains are covered by the white and pink flowers. Since 2015, "The Buckwheat Festival" has been organized annually that lasts for a month, starting from the early November till December, in order to encourage the preservation and development of ethnic cultures and create more jobs for the local population (www4).

Cultural activities are important elements of the conservation plan in the DVKP. In this area, 17 ethnic groups live together, bringing a unique architecture to this area. They trade goods together in a special fair (Fig. 16) and build a wall from the limestone rocks in the local area ( Fig. 17).

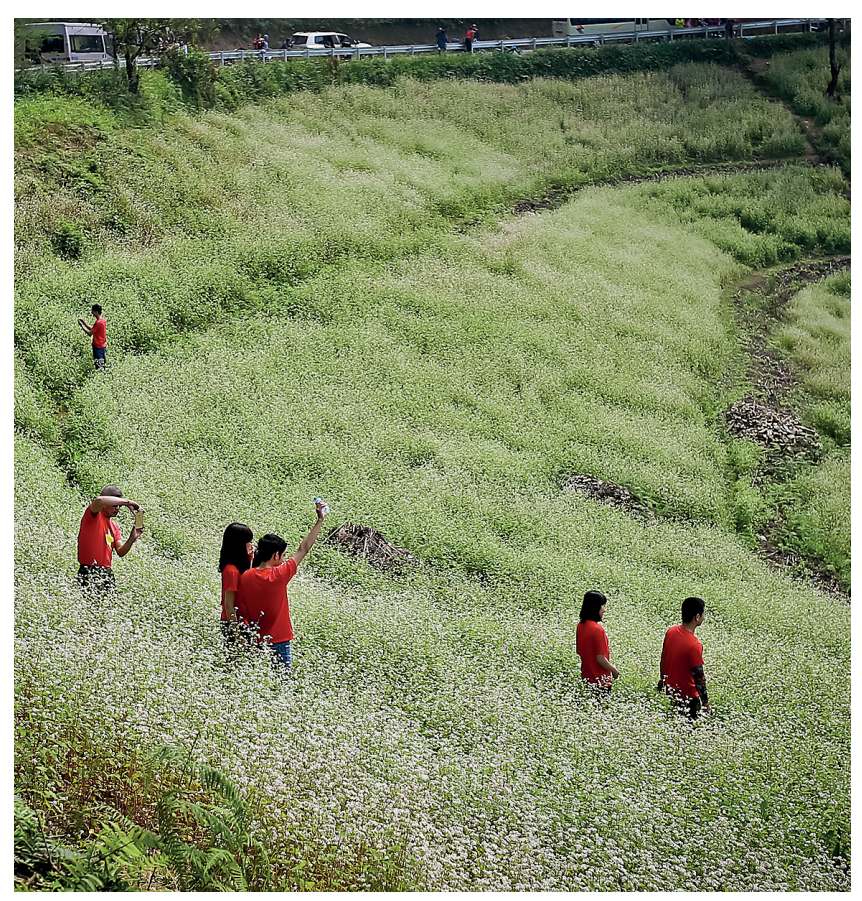

Fig. 15. Buckwheat flowering in Yen Minh district, photo Thanh Nam 


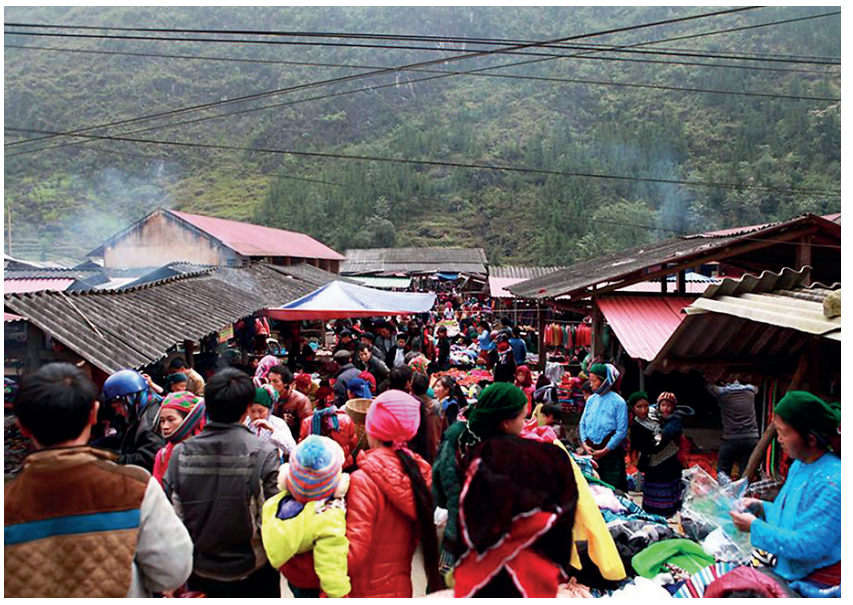

Fig. 16. Local fair in Yen Minh district, photo Dao Quoc Bao

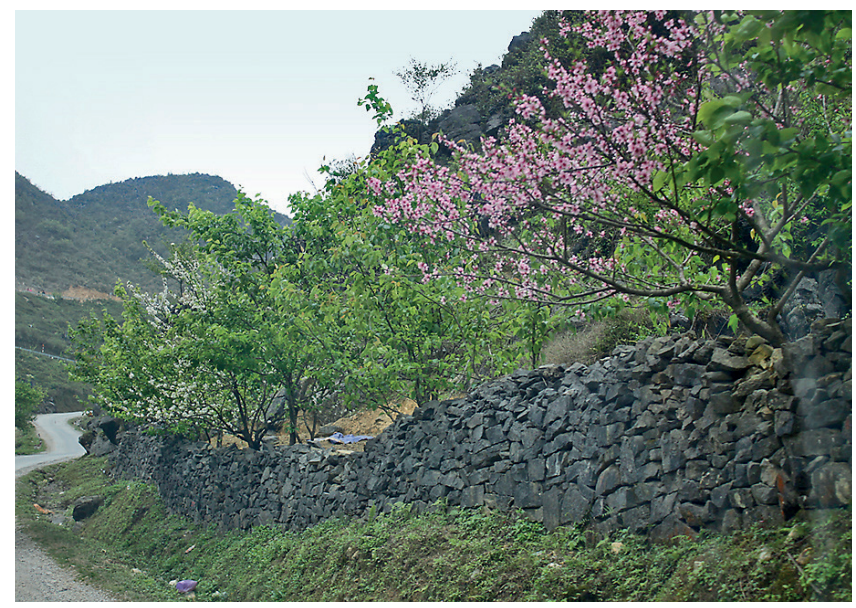

Fig. 17. The wall made of limestone in Dong Van district, photo Dao Quoc Bao

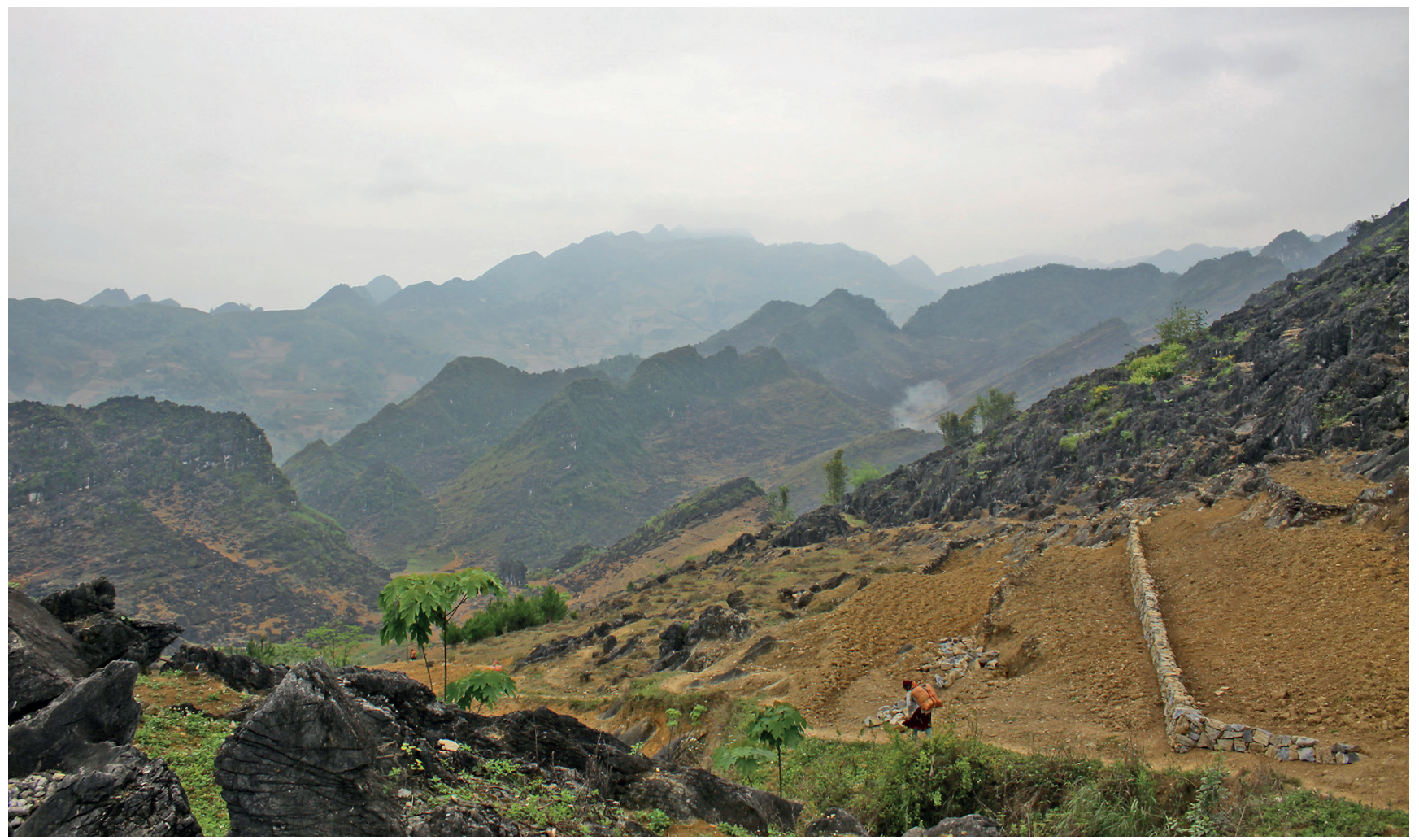

Fig. 18. Local people building a rock wall for farming to keep water and avoid soil erosion using local material in the Dong Van district, photo Dao Quoc Bao

A cultural and tourism village is going to be built for preserving and promoting the traditional cultural values of the ethnic groups. This will create a venue for them to perform traditional songs and dances, play folk games and develop traditional crafts such as weaving, thus improving their living conditions (www3). Around all the tourist attractions in the DVKP, the local people have permission to run souvenir shops, to provide the local food and homestay services. Although the Ha Giang is one of Vietnam's poorest areas, with a low level of income, education and health service, the local people's perpetual survival is a testament to their indomitable spirits, using rocks to make small dams to keep water and avoid soil erosion. while cutting the sloping plain into a series of platforms, to make farming more effectively (Fig. 18). The authorities expect that the local residents will be able to improve their financial status in their motherland gained from these services and will also conserve their cultural tradition through these activities. 


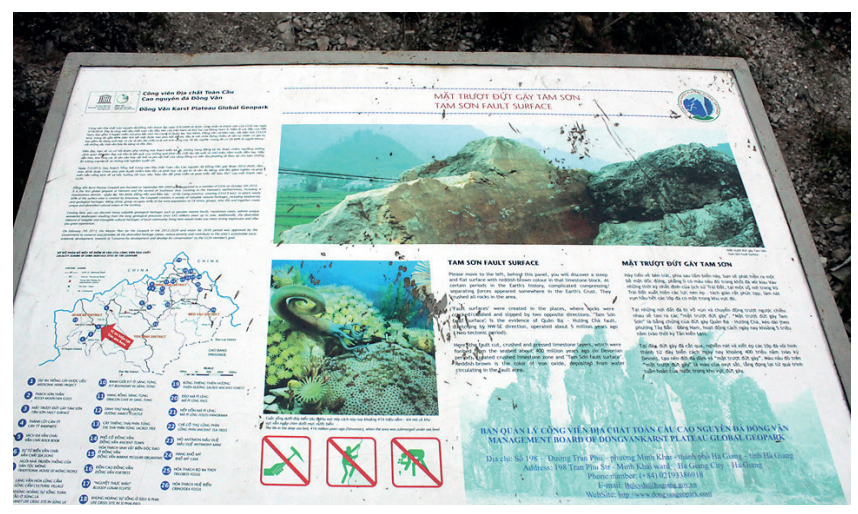

Fig. 19. Educational board describing the "Tam Son Fault Surface" geosite in the area of DVKP, photo Dao Quoc Bao

In terms of educational activity, all these geosites were documented, and each geosite has an information board (Fig. 19) in both English and Vietnamese, in order to provide clear information for tourists and students. Several classes and training courses have been organized for local people to expand their knowledge of the value of these geosites and to prevent any actions resulting in their damage. All of these activities are funded by the state budget. In order to enhance the understanding of Geopark ideas by geoscience students and by local communities, many students prepare scientific research projects concerning the DVKP, supported by universities and state authorities. It is expected that the new generation of geologists will inherit and expand the nature treasures of the DVKP.

\section{Discussion and conclusion}

The unique karst landscape of the Dong Van Global Geopark is influenced by the diversity of lithologies and several phases of tectonic evolution, which took place between the Middle Cambrian-Early Ordovician and the Cenozoic. Several karst caves from the total number of 100 caves in this area, together with sinkholes and other valuable objects of geological heritage, which formed due to the combined action of tectonic and erosional processes, represent tourist attractions.

The DVKP is highly rated by scientists for its geoscientific values, unique in the world, with many manifestations of geoheritage that have been formed throughout the last 540 million years. It is a tropical climate mountainous area, but it has the potential to become an international tourist attraction.

In order to raise the DVKP up to a higher level of geopark practice, the authorities still have much to do. This geopark must obtain the strong involvement of the local authorities, state investment and the development of specific concepts and proposals on how to generate a balanced combination of geological solutions, research and promotion solutions as well as the sustainable development of the economy, ensuring a better life for the local people. The development plan should be based on geological knowledge of the region and its inherent values. In parallel, environmental protection activities; training human resources in a professional manner, improving the quality of services and creating more new tourism products could also contribute to the beauty of the DVKP, attracting domestic and international tourists alike.

\section{Acknowledgements}

Our appreciation goes to the Polish National Commission for UNESCO, the UNESCO Chair for Science, Technology and Engineering Education at the AGH University of Science and Technology, and the Department of General Geology and Geotourism at Faculty of Geology, Geophysics and Environment Protection for supporting this paper which is a part of the UNESCO/Poland Co-Sponsored Fellowships Programme in Engineering, Edition 2017A of the first author. In addition, the authors wish to thank Professor Hoang Van Long - the Deputy Head of Geophysical Division, General Department of Geology and Minerals of Vietnam and Mr. Dao Quoc Bao, the Hanoi University of Mining and Geology for their contribution in collecting data and providing the information.

\section{References}

Deharveng L., Le C.K., Le C.M. \& Bedos A., 2004. Hot issues in karst conservation: the biodiversity of Hon Chong hills (southern Vietnam), with emphasis on invertebrate endemism. In: Batelaan O., Dusar M., Masschelein J., Van T.T., Tam V.T., \& Khien N.X. (eds), Proceedings of Trans - Karst 2004 International Transdisciplinary Conference on Development and Conservation of Karst Regions. Hanoi, Vietnam, 13-18.09.2004, Research Institute of Geology and Mineral Resources, 40.

Faure M., Shu L., Wang B., Charvet J., Choulet F. \& Monie P., 2009. Intracontinental subduction: a possible mechanism for the Early Paleozoic Orogen of SE China. Tera Nova, 21. doi:10.1111/j.13653121.2009.00888.x.
Hoang X.T., 2010. Geological and mineral map of Dong Van area, scale $1 / 200,000$. Institute of Information, Archive and Museum, Department of Geology and Mineral Resources, Ministry of Natural Resources and Environment, Vietnam.

Hoang V.S., Phan V.D., Dao T.L., Dan T.H.P., Pham V.D., Nguyen T.C., 2016. Conservation of threatened plant species in Dong Van Kart Plateau Geopark, Ha Giang province. Journal of Forest Science and Technology, 3: 118-125.

Hutchison C.S., 1989. Geological evolution of South-East Asia. Oxford University Press, Oxford.

Krobicki M., Golonka J., Pająk J., Słomka T. \& Ngo V.H., 2006. Karst regions and processes in the north Vietnam and their geoturistic significance. Geoturystyka, 1(4): 51-70. 
La T.P., Tran T.V., Luong T.T., Doan T.A., Ho T.C., Dang T.H., Nguyen X.K., Dam N., Do Thi Y.N., Nguyen D.T., Pham K.T. \& Truong Q.Q., 2011. Dong Van rock highland - the first international Geopark of Vietnam and geoheritage preservation. Vietnam Journal of Earth Sciences, 33(1): 45-54. Available from: http://vjs.ac.vn/index.php/jse/article/view/271 [accessed: 2018.01.03].

Metcalfe I., 2005. Asia: South-East. In: Selley R., Cocks R. \& Plimer I. (eds), Encyclopedia of geology, Elsevier Ltd, Oxford: 169-198.

Ministry of Natural Resources and Enviromental of Vietnam, 2016. The 1 : 50000 scale map of Vietnam 'topography. Geological Storage Center-General Department of Geology and Minerals of Vietnam, Hanoi.

Newsome D. \& Dowling R.K., 2010. Geotourism: The Tourism of Geology and Landscape. Goodfellow Publishers Ltd, Woodeaton, Oxford.

Nguyen C.T., 2005. Report on geological mapping and mineral resource assessment at 1:50,000 scale of Trung Khanh map sheets, Cao Bang Province. Department of Geology and Minerals of Vietnam, Hanoi.

Nguyen T.D., 2006. Report on Geological Mapping and Mineral resources assessment at $1: 50,000$ scale of Bac Kan map sheets, Bac Kan Province. Department of Geology and Minerals of Vietnam, Hanoi.

Nguyen V.L., Nguyen K.N., Hoang V.H., Tran Q.T. \& Vu T.N., 2013. The characteristics of karstic water in Northeast region of Vietnam. Environmental Earth Sciences, 70. doi.org/10.1007/s12665-012-1548-8.

Nguyen X.T., 2011. Geological features and physical geography of Dong Van stone plateau geopark, Ha Giang province. Ho Chi Minh City University of Education, Journal of Science, 29: 115-124.

Pająk J., Golonka J.\& Krobicki M., 2006. Attractions of unanimated nature of the northern Vietnam as a basis for tourist development. Geoturystyka, 1(4): 5-25.

Pająk J., Golonka J., Krobicki M., Nguyen V.G. \& Zuchiewicz W. 2006. Exploring the northwestern mountain area of Vietnam. Ancient and modern orogens, geotouristic objects and geological processes. Geoturystyka, 1(4): 27-49.

Pham K., 1985. The development of karst landscapes in Vietnam. Acta Geologica Polonica, 35(3-4): 305-323.

Pham T.L., Dang D.L., Vu T.C., Nguyen V.B. \& Nguyen N.K., 2000. The Tourism resources and environment in Vietnam. Vietnam Education Publishing House Limited Company, Hanoi.

Pham V.H., Tran T.V., Quach D.T., Ho H.H., Nguyen D.T. \& Nguyen Q.H., 2013. Geoheritage values of the Dong Van Karst Plateau Geopark: A quantitative geomorphological and topographic analysis. Bulletin of the Geological Society of Malaysia, 59: 13-17.

Searle M.P., 2006. Role of the Red River Shear zone, Yunnan and Vietnam, in the continental extrusion of SE Asia. Journal of the Geological Society, 163(6). doi. 10.1144/0016-76492005-144.

Tapponnier P., Peltzer G. \& Armijo R., 1986. On the mechanics of the collision between India and Asia. In: Coward M.P. \& Ries A.C. (eds), Collision tectonics. Geological Society, London, Special Publications, 19: 115-157.
Tapponnier P., Lacassin R., Leloup P.H., Schärer U., Dalai Z., Haiwei W., Xiaohan L., Shaocheng J., Lianshang Z. \& Jiayou Z., 1990. The Ailao Shan/Red River metamorphic belt: tertiary left-lateral shear between Indochina and South China. Nature, 343: 431-437.

The Political Bureau of the Party Central Committee of Vietnam: NQ08/TW, 2017, Tourism - A Key Economic Sector. Hanoi.

Tran T.H., Nguyen V.C. \& Nguyen C.T., 2004. High resolution structural analysis of multiply deformed regions and its significance in geological history of the northeastern Cao Bang area, Northern Vietnam. In: Nguyen V.C. (ed.), Geology and minerals of Vietnam. General Department of Geology and Minerals of Vietnam, Hanoi: 99-116.

Tran T.V., Lagrou D., Masschelein J., Dusar M., Ke T.D., Viet H.A., Quyet D.X., Thang D.V., Chung H.T. and Anh D.T., 2004. Karst water management in Dong Van and Meo Vac districts, Ha Giang province, Vietnam. Contribution of geological and speleological investigations. In: Batelaan O., Dusar M., Masschelein J., Van T.T., Tam V.T., \& Khien N.X. (eds), Proceedings of Trans - Karst 2004 International Transdisciplinary Conference on Development and Conservation of Karst Regions. Hanoi, Vietnam, 13-18.9.2004. Research Institute of Geology and Mineral Resources, 265-271.

Tran T.H., 2009. Deformational features of Northeastern Vietnam. In: Tran V.T. \& Vu K. (eds), Geology and natural resources of Vietnam, Natural Sciences and Technology Publishing House, Hanoi: 408-415.

Tran T.H., Dang B.V., Ngo C.K., Hoang Q.D. \& Nguyen Q.M., 2011. Structural controls on the occurrence and morphology of karstified assemblages in northeastern Vietnam: a regional perspective. Environmental Earth Sciences, 70(2). doi.org/10.1007/s12665-0111057-1.

Tran T.V., Nguyen D.T., Luong T.T. \& Ho T.C., 2011. Field Guide To Dong Van Karst Plateau Global Geopark, Ha Long Bay World Natural Heritage And Cat Ba Archipelago World Bio-Sphere Reserve. Vietnam Institute of Geosciences and Mineral Resources, Hanoi.

Tran V.T. \& Vu K., 2009. Geology and natural resources of Vietnam. Natural Sciences and Technology Publishing House, Hanoi.

Vu T.T. \& Batelaan O., 2011. A multi-analysis remote-sensing approach for mapping groundwater resources in the karstic Meo Vac Valley, Vietnam. Hydrogeology Journal, 19(2). doi.org/10.1007/s10040010-0684-z.

www1 - www.data.worldbank.org/indicator/ST.INT.ARVL?locations $=\mathrm{VN}$ [accessed: 21.12.2017]

www2 - www.globalgeopark.org/aboutGGN/list/Vietnam/6509.htm [accesed: 21.12.2017]

www3 - http://vanban.chinhphu.vn/portal/page/portal/chinhphu/hethongvanban?class_id $=2 \& \_p a g e=1 \&$ mode $=$ detail\&document $\_$id $=$ 192302 [accessed: 29.12.2017]

www4 - http://hagiang.gov.vn/sites/en-us/Pages/home.aspx [accessed: 29.12.2017] 